\title{
Nucleation of Fe-rich phosphates and carbonates on microbial cells and exopolymeric substances
}

\author{
Mónica Sánchez-Román ${ }^{1 *}$, Fernando Puente-Sánchez ${ }^{2}$, Víctor Parro ${ }^{2}$ and \\ Ricardo Amils ${ }^{1,3}$
}

${ }^{1}$ Department of Planetology and Habitability, Centro de Astrobiología (INTA-CSIC), Madrid, Spain, ${ }^{2}$ Department of Molecular Evolution, Centro de Astrobiología (INTA-CSIC), Madrid, Spain, ${ }^{3}$ Department of Virology and Microbiology, Centro de

Biología Molecular Severo Ochoa, Madrid, Spain

OPEN ACCESS

Edited by:

Maria Dittrich

University of Toronto, Canada

Reviewed by:

Javier Alvaro,

Centre of Astrobiology, Spain

Mohamed Larbi Merroun,

University of Granada, Spain

Muriel Pacton,

Université Lyon 1, France

*Correspondence:

Mónica Sánchez-Román,

Department of Planetology and

Habitability, Centro de Astrobiología

(INTA-CSIC), Ctra. Ajalvir. Km 4 ,

Torrejón de Ardoz,

28850 Madrid, Spain

sanchezromanmonica@gmail.com

Specialty section:

This article was submitted to Microbiotechnology, Ecotoxicology

and Bioremediation,

a section of the journal

Frontiers in Microbiology

Received: 29 April 2015

Accepted: 26 August 2015

Published: 22 September 2015

Citation:

Sánchez-Román M, Puente-Sánchez F, Parro $V$ and Amils R (2015) Nucleation of Fe-rich phosphates and carbonates on microbial cells and exopolymeric substances. Front. Microbiol. 6:1024. doi: 10.3389/fmicb.2015.01024
Although phosphate and carbonate are important constituents in ancient and modern environments, it is not yet clear their biogeochemical relationships and their mechanisms of formation. Microbially mediated carbonate formation has been widely studied whereas little is known about the formation of phosphate minerals. Here we report that a new bacterial strain, Tessarococcus lapidicaptus, isolated from the subsurface of Rio Tinto basin (Huelva, SW Spain), is capable of precipitating Fe-rich phosphate and carbonate minerals. We observed morphological differences between phosphate and carbonate, which may help us to recognize these minerals in terrestrial and extraterrestrial environments. Finally, considering the scarcity and the unequal distribution and preservation patterns of phosphate and carbonates, respectively, in the geological record and the biomineralization process that produces those minerals, we propose a hypothesis for the lack of Fe-phosphates in natural environments and ancient rocks.

Keywords: microbial, bacterial precipitates, nanoglobules, Tessarococcus, vivianite, siderite

\section{Introduction}

Authigenic ferrous iron-rich minerals like vivianite $\left[\mathrm{Fe}_{3}\left(\mathrm{PO}_{4}\right)_{2} \times 8 \mathrm{H}_{2} \mathrm{O}\right]$ and siderite $\left(\mathrm{Fe}_{2} \mathrm{CO}_{3}\right)$ are used as indicators of paleoenvironmental conditions, diagenetic evolution of sedimentary sequences (Last and De Deckker, 1990; Manning et al., 1999; Sapota et al., 2006) and biosignatures (Vuillemin et al., 2013; Sánchez-Román et al., 2014). They are usually found associated in organic rich environments like lacustrine (Lemos et al., 2007; Rothe et al., 2014) and deep-sea sediments (Dijkstra et al., 2014), swamps, sewage, and wastewater treatment plants (Postma, 1981; Lovley et al., 1991). Vivianite is considered the most important sink of phosphorus in reducing natural systems, being a significant parameter controlling the trophic status of lakes (Nriagu and Dell, 1974; Manning et al., 1991). Therefore, it can exert significant controls over the geochemical cycles of $\mathrm{P}$ and Fe (Veeramani et al., 2011) in reducing sediments in which iron and phosphorous are highly mobile and the sulfide ion is not produced in high concentration (Manning et al., 1991). On the other hand, the majority of the carbonate minerals on Earth surface are of biogenic origin (Moore, 1989; Riding, 2006) and the process of carbonate precipitation can be the most important factor controlling the global carbon cycling (Ridgwell and Zeebe, 2005; Dupraz et al., 2009). Vivianite and siderite usually occur associated with pyrite $\left(\mathrm{FeS}_{2}\right)$ in veins of copper, tin, iron, and gold ores (Craig and Vaughan, 1994; Wiberg et al., 2001). Furthermore, these two iron-rich minerals are used as iron fertilizer (Eynard et al., 1992; Rakshit et al., 2008; Sánchez-Alcalá et al., 2012) and 
more rarely vivianite has been used as phosphorous fertilizer (Mikhailov, 1940; Nelipa, 1961). In addition, vivianite is also found in decaying plants and animal tissues, bones, shells, anthropogenic compounds, human wastes, and archeological settings (Jakobsen, 1988; McGowan and Prangnell, 2006; Nutt and Swihart, 2012).

Vivianite is a significant mineral because links forensic medicine (Thali et al., 2011), physical anthropology (McGowan and Prangnell, 2006), biology and climate geology (Sapota et al., 2006). On the other hand, siderite is also an important carbonate mineral that provides information about past climatic events on Earth and Mars (Ellwood et al., 1998; Fairen et al., 2004; Tomkinson et al., 2013). Actually, siderite and vivianite are significant constituents of martian meteorites and Mars surface (Valley et al., 1997; Dyar et al., 2014). In contrast to vivianite, siderite is found in much greater abundance in ancient rocks than in modern environments (Ohmoto et al., 2004; Kholodov and Butuzova, 2008). The formation of these two iron rich minerals is generally attributed to the activity of iron reducing bacteria (Mortimer and Coleman, 1997; Orange et al., 2009; Lee et al., 2010), and they have significant implications for microbial metabolism in sediments (Fredrickson et al., 1998). It is known that siderite can be formed within the sub-oxic, sulfate-reducion and methanogenic biogeochemical zones within the sediment column (Wilkinson et al., 2000).

Recently, Fe-rich sulfide (pyrite), sulfate [jarosite, $\left.\mathrm{KFe}_{3}(\mathrm{OH})_{6}\left(\mathrm{SO}_{4}\right)_{2}\right]$, and carbonate (siderite) minerals have been found in Rio Tinto basin (Fernández-Remolar et al., 2012) and their formation have been also related to iron-reducing fungi and bacteria (Oggerin et al., 2013; Sánchez-Román et al., 2014). Those minerals together with vivianite are known as important minerals in the iron biogeochemical cycle (Raiswell and Canfield, 2012). Rio Tinto is an acidic system in which microorganisms play an important role by determining the speciation of iron and can also cause considerable iron accumulation through biomineralization (Fernández-Remolar et al., 2012; Oggerin et al., 2013; Sánchez-Román et al., 2014). Furthermore, this acidsulfate system enriched in iron is considered one of the potential analogs for early life on Earth and Mars (Fernández-Remolar et al., 2012). In order to better understand the nucleation and formation processes of iron carbonate and phosphate minerals, here, we present for the first time microbially mediated primary precipitation of siderite and vivianite in anaerobic culture experiments under Earth's surface conditions using a bacterial strain, Tessarococcus lapidicaptus, isolated from the subsurface of Rio Tinto (Puente-Sánchez et al., 2014a). The nucleation, chemical composition, texture and morphology of the bioprecipitates have been studied using a combination of high resolution transmission electron microscopy (TEM), scanning electron microscopy (SEM), sensitive energy dispersive $\mathrm{X}$-ray Spectroscopy (EDS), and X-ray powder diffraction (XRD). We demonstrate that $T$. lapidicaptus produces spatially restricted supersaturated conditions and can overcome kinetic barrier to nucleate phosphate and carbonate nanocrystals in its cells and secreted EPS, respectively. We propose that microbial nanostructures, nanocrystals, and crystalline nanoparticles, are not related to a single microbial group or to a specific microbial metabolism but to a wide range of microorganisms. Finally, we discuss the mechanism of formation of both phosphate and carbonate and their significance and implication in natural systems.

\section{Materials and Methods}

\section{Microorganism}

Tessaracoccus lapidicaptus CECT 8385 (= DSM 27266) is a gram-positive, non-spore forming, oval to rod shaped, nitratereducing, and facultatively anaerobic Actinobacterium. The growth temperature ranges from 15 to $40^{\circ} \mathrm{C}$ (optimal at $37^{\circ} \mathrm{C}$ ) and the growth $\mathrm{pH}$ range from 6 to 9 (optimal at 8). It was isolated from a $297 \mathrm{~m}$ depth-drilling core obtained from the Iberian Pyrite Belt (Puente-Sánchez et al., 2014a). Only the innermost part of the core was sampled, and sodium bromide was added to the drilling water as a tracer for potential contamination, as described in Amils et al. (2013).

Two members of the Tessaracoccus genus have been previously isolated from marine sediments (Lee and Lee, 2008) and deep subsurface environments (Finster et al., 2009). Others have been isolated from crude oil-contaminated saline soil (Cai et al., 2011) and oleaginous, water-mixed metalworking fluids (Kämpfer et al., 2009), which suggests that the Tessaracoccus genus might be specially adept at degrading hydrocarbons and/or recalcitrant organic matter under harsh environmental conditions.

\section{Culture Medium}

The composition of the anoxic medium $\mathrm{FE}$ used in this study was (wt/vol): $0.25 \% \mathrm{NaCl} ; 0.04 \% \mathrm{NH}_{4} \mathrm{Cl} ; 0.003 \% \mathrm{MgCl}_{2} \cdot 6 \mathrm{H}_{2} \mathrm{O}$; $0.005 \% \mathrm{CaCl}_{2} \cdot 2 \mathrm{H}_{2} \mathrm{O} ; 0.2 \% \mathrm{FeCl}_{2} \cdot 4 \mathrm{H}_{2} 0 ; 0.01 \%$ yeast extract; $0.085 \% \mathrm{NaNO}_{3} ; 0.1 \%$ glucose; $0.1 \%$ succinic anhidryde; $0.05 \%$ $\mathrm{KH}_{2} \mathrm{PO}_{4} ; 0.025 \% \mathrm{NaHCO}_{3} ; 0.05 \%$ cysteine hydrochloride; $0.01 \%$ resazurin. The $\mathrm{pH}$ of the medium was 6 and it was sterilized at $121^{\circ} \mathrm{C}$ for $20 \mathrm{~min}$.

\section{Study of Crystal Nucleation and Precipitation}

T. lapidicaptus was inoculated into liquid cultures which were carried out in $100 \mathrm{ml}$ bottles containing $100 \mathrm{ml}$ of FE medium. The bottles containing the culture medium were incubated anaerobically at $30^{\circ} \mathrm{C}$ and examined periodically for the presence of minerals for up to 45 days after incubation. Controls consisting of uninoculated culture media and media inoculated with non-viable cells were included in all the experiments. $\mathrm{pH}$ measurements were performed at the end of the growth and mineral formation.

The optical density (OD) of the inocula was 0.5 at a wavelength of $600 \mathrm{~nm}$. It was analyzed using a Spectronic 20 Genesys spectrophotometer. The $\mathrm{Fe}^{2+}$ was measured using a RQflex 10 Merck reflectoquant.

\section{Mineral Analysis}

The crystals were examined by X-ray diffraction (XRD) using a PANlytical X'Pert MPD PW3011/10. A JEOL JSM 6335 scanning electron microscope (SEM), equipped with a spectroscope of dispersive energy (EDX), was used for imaging and elemental 
analysis of single crystals. The mineral precipitates were also analyzed by transmission electro microscopy (TEM) under JEOL JEM 2100, $200 \mathrm{KV}$ TEM with a CCD camera model 832. The morphology of the cells and crystal precipitates were examined with a JEOL JEM-1010 (TEM). TEM sample preparation is described in Ferrero et al. (2013) but without adding 5\% $\mathrm{K}_{3} \mathrm{Fe}(\mathrm{CN})_{6}$ in the post-fixation step.

\section{Geochemical Studies}

The activity of dissolved species and the degree of saturation in the solutions assayed were determined using the geochemical computer program PHREEQC version 2 (Parkhust and Appelo, 1999). The results from PHREEQC are presented in terms of the saturation index (SI) for each predicted mineral. SI is defined by $\mathrm{SI}=\lg (\mathrm{IAP} / \mathrm{Ksp})$, where IAP is the ion activity product of the dissolved mineral constituents in a solubility product (Ksp) for the mineral. Thus, SI $>0$ implies oversaturation with respect to the mineral, whereas SI $<0$ means undersaturation.

\section{Results}

The mineral precipitates formed exclusively in culture bottles with active bacterial cells, while no mineral precipitation occurred in sterile parallel controls (bottles with non-viable cells and without cells). The $\mathrm{pH}$ changed from 6 to $\sim 7.5$ in cultures with living bacteria. No change in $\mathrm{pH}$ was detected in the control experiments. The starting concentration of $\mathrm{Fe}^{2+}$ was $0.56 \mathrm{~g} / \mathrm{L}$ and the final concentration, after mineral precipitation, $0.01 \mathrm{~g} / \mathrm{L}$. The XRD study reveals that the bioprecipitates are composed of vivianite and siderite, being vivianite the dominant mineral phase (Figure 1).

TEM and SEM images of the bacterial precipitates show that Fe-phosphate crystals and Fe-carbonate spheroidal nanoparticles (nanoglobules) and in some cases, elongated nanoparticles were attached to the bacterial cells and EPS (Figures 2A-D, 3A,B,D, 4A,B). EDX analyses (Figures 2F-H) confirm the X-ray results, the nanoparticle precipitates are composed of both, vivianite and siderite. Vivianite crystals have a prismatic or tabular habit and form coarse radial-fibrous aggregates like rosettes with a high degree of crystallinity and vitreous luster (Figures 3C,D). These crystals are approximately $10-20 \mu \mathrm{m}$ in width and $100-300 \mu \mathrm{m}$ in length. Siderite crystals are aggregates of nanoglobules with a diameter 20-100 nm (Figures 4A,B). These nanoglobules were attached to T. lapidicaptus cells and embedded in a thin organic film (exopolymeric substances or EPS) produced by $T$. lapidicaptus during its growth (Figures 2A-D, 4A,B). Mineralized bacteria were clearly recognized (Figures $\mathbf{3 A}, \mathbf{4 A}$ ) as well as dividing cells (Figures 2B, 4A); broken cells and mould of degraded cells (Figures 3A, 4B). The process of microspherulites (diameter $>10 \mu \mathrm{m}$ ) formation comprises a sequence of events, starting with the appearance of bacterial nanoglobules $(<20 \mathrm{~nm})$ to larger ones $(>100 \mathrm{~nm})$, which agglomerate with time resulting in microspherulites (Figures 4C,D). The most important process in the sequence that leads to the formation of spherulites is the accumulation of nanoglubules and mineralized bacterial cells, embedded in EPS matrix, displaying a granulated texture (Figures 4A,B,D).
Mineral phases with SI values positive or very close to 0 (above or below the equilibrium point) were observed, suggesting the possibility for inorganic (chemical) precipitation in the aqueous medium assayed (Table 1). These SI data were obtained by applying the geochemical software PHREEQC to the ionic composition of the culture medium. According to these data, the culture FE medium is saturated in hydroxiapatite, vivianite, and siderite.

\section{Discussion}

\section{Nucleation and Precipitation of Phosphate and Carbonate by T. Lapidicaptus}

Our TEM and SEM studies showed that carbonate and phosphate nanocrystals nucleated on bacterial cell surfaces and EPS (Figures 2, 3, 4). The initial step of nucleation of carbonate and phosphate spheroidal nanocrystals occurs in the outer side of the bacterial envelopes (cell wall) and within EPS in intimate association with the bacteria cell surface (Figures 2A-D, 3A, 4A,B). Later carbonate spherulites and elongated phosphate crystals are formed by aggregation of nanocrystals embedded in the EPS matrix (Figures 2E, 3A,B, 4A,B,D). We also observed mineralized bacterial cells embedded in the surface of the crystals (Figures 3A, 4A). Similar nanocrystals have been previously reported for culture experiments using sulfate reducing-bacteria, aerobic heterotrophic bacteria, acidophilic iron-reducing bacteria and fungi (Aloisi et al., 2006; Bontognali et al., 2008; Sánchez-Román et al., 2008, 2014; Oggerin et al., 2013). These findings lead us to propose that microbial nanostructures such as nanocrystals and crystalline nanoparticles are not related to a single microbial group or to a specific microbial metabolism but to a wide range of microorganisms including bacteria and fungi. However, the mineralogy composition of such nanostructures would depend on the physico-chemical properties of the precipitating solution (chemistry, $\mathrm{pH}$, salinity, etc.,) and on the type of microorganism involved in the precipitation.

The aqueous culture medium used in these experiments is saturated with respect to vivianite and siderite (Table 1), there is a tendency toward their abiotic precipitation. The calculated saturation indexes (Table 1) for vivianite and siderite indicate that they should have been abiotically precipitated in the solution, in the absence of bacteria. However, no mineral precipitation was observed in the control experiments (without and with nonviable cells), while in living culture experiments (with active cells) vivianite and siderite precipitated. These data confirm that an aqueous solution saturated with certain mineral phase(s) does not imply abiotic precipitation with respect to those minerals, but it depends on their precipitation kinetics (Morse, 1983). Therefore, vivianite and siderite precipitation can be attributed to the presence of living $T$. lapidicaptus cells which are capable of overcoming the kinetic barriers for mineral precipitation, i.e., reducing the activation energy barriers. The metabolic activity of the bacteria is very important because it supplies the ions necessary for the formation of minerals, $\mathrm{PO}_{4}{ }^{3-}$ for phosphates and $\mathrm{CO}_{3}{ }^{2-}$ for carbonates. Additionally, the appropriate microenvironment around bacterial cells and EPS (increase $\mathrm{pH}$ 


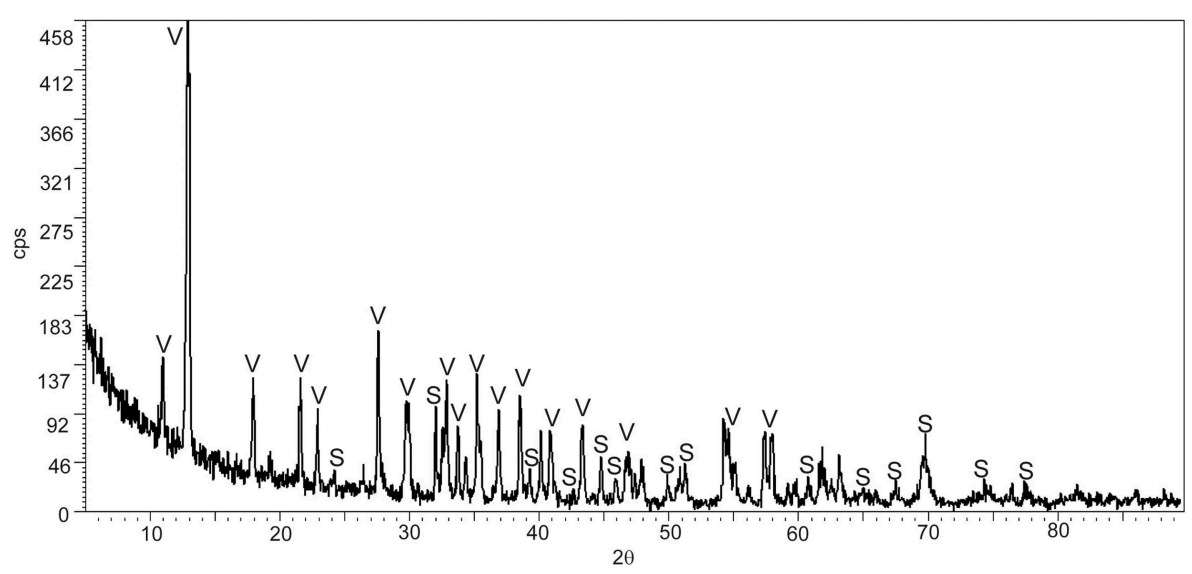

FIGURE 1 | X-ray diffractogram of the bioprecipitates formed in T. Lapidicaptus anaerobic cultures. V, Vivianite; S, siderite.

and/or ionic concentration) is created for mineral precipitation. In fact, an increase in the $\mathrm{pH}$ from 6 to 7.8 in the cultures with active cells was measured. No mineralization was observed in the control experiments where no $\mathrm{pH}$ alteration was detected.

Bacteria induce mineral precipitation by concentrating ions (e.g., $\mathrm{Ca}, \mathrm{Fe}, \mathrm{Mg}, \mathrm{CO}_{3}{ }^{2-}, \mathrm{PO}_{3}{ }^{4-}, \mathrm{NH}_{4}^{+}$) and changing the $\mathrm{pH}$ in the microenvironment surrounding their cells (Ehrlich, 2002; van Lith et al., 2003; Sánchez-Román et al., 2011). Bacterial cells act as a template for mineral nucleation by adsorbing ions around the cellular surface membrane or cell wall (Schultze-Lam et al., 1996; Bosak and Newman, 2003). This process does not occur in absence of bacterial activity. Moreover, EPS are considered as important factor for mineral precipitation (Dupraz et al., 2004; Aloisi et al., 2006; Ercole et al., 2007; Bontognali et al., 2008; Krause et al., 2012). The charged cell walls as well as the reactive groups of the EPS provide active interfacial sites for adsorption and complexation of dissolved aqueous metal species, inducing the nucleation and precipitation of minerals by reducing the activation energy barriers (Konhauser, 1998; De Yoreo et al., 2013; Habraken et al., 2013). This results in a mineralized cellular matrix containing detectable concentrations of metallic ions that are not easily re-dissolved (Beveridge and Fyfe, 1985). During bacterial growth experiments using an aqueous medium rich in organic compounds (yeast extract, glucose, succinic anhidryd, cysteine) source for $\mathrm{CO}_{2}, \mathrm{NH}_{3}$ and $\mathrm{HPO}_{3}{ }^{2-}$, the $\mathrm{pH}$, carbonate and phosphate concentrations increased because of the production of $\mathrm{CO}_{2}, \mathrm{NH}_{3}$, and $\mathrm{HPO}_{3}{ }^{2-}$ (which hydrate to form $\mathrm{CO}_{3}{ }^{2-}, \mathrm{NH}_{4}^{+}$and $\mathrm{PO}_{4}{ }^{3-}$ ) during metabolization of organic compounds.

These changes together with the adsorption of iron ions by T. lapidicaptus would lead to local supersaturation gradients around bacterial surfaces and EPS, using these as nucleation sites to induce iron phosphate and carbonate precipitation as previously has been demonstrated for other type of bacteria (Aloisi et al., 2006; Bontognali et al., 2008; Sánchez-Román et al., 2008, 2011, 2014).

It is essential to understand how super-saturation and nucleation develop in our culture experiments. If concentration of ions in solution exceeds the solubility product for a solid mineral phase, precipitation will not occur until a certain degree of supersaturation is achieved (Berner, 1980). The process during which the maximum free energy is attained is known as nucleation and involves the growth of critical crystal nuclei (Jack et al., 1993; Sánchez-Navas et al., 2009). This process is accompanied by a decrease in free energy and is referred to as crystal growth. The presence of living bacteria can promote either process. Here, the surface of the microbial cell and EPS provides a template on which nucleation can occur and overcome kinetic barriers to facilitate mineral precipitation as previously expounded. This reduces the free energy required during the nucleation step and focuses crystal growth because nucleation on the biological template occurs before nucleation in homogeneous solution (Jack et al., 1993). Most types of bacteria are capable of acting as nucleation templates (Beveridge and Fyfe, 1985). Although abiotic precipitation is difficult in natural systems or in sterile laboratory experiments (present work), the presence of bacteria can induce the precipitation of minerals in microenvironments by (1) modifying the conditions of their surrounding environments and/or concentrate ions in the bacterial cell envelope and (2) acting as nucleation sites.

Apparently, siderite and vivianite have many physicochemical characteristics in common. However, morphological details suggest different nucleation and growth conditions. In most cases, siderite nucleates on the bacterial cell wall and with time develops into a microspherulite (Figures 2A-C, 4A-D); and vivianite nucleates on the bacterial cell and within the EPS on nanocrystals that agglomerate and get alone as elongated (rosette) crystals (Figures 2A-E, 3A-D). On the other hand, $\mathrm{PO}_{4}{ }^{3-}$ inhibits the precipitation of carbonate minerals (Bouropoulos and Koutsoukos, 2000; Kofina and Kotsoukos, 2005; Morse et al., 2007). Whereas, the presence of phosphate can inhibit the formation of siderite (Fredrickson and Gorby, 1996). Indeed, when phosphate is present, vivianite appears to be the stable end product due to its lower solubility product $\left(\mathrm{Ksp}=10^{-36}\right.$ ) (Glasauer et al., 2003). In our cultures, vivianite precipitated first than siderite. Organic 


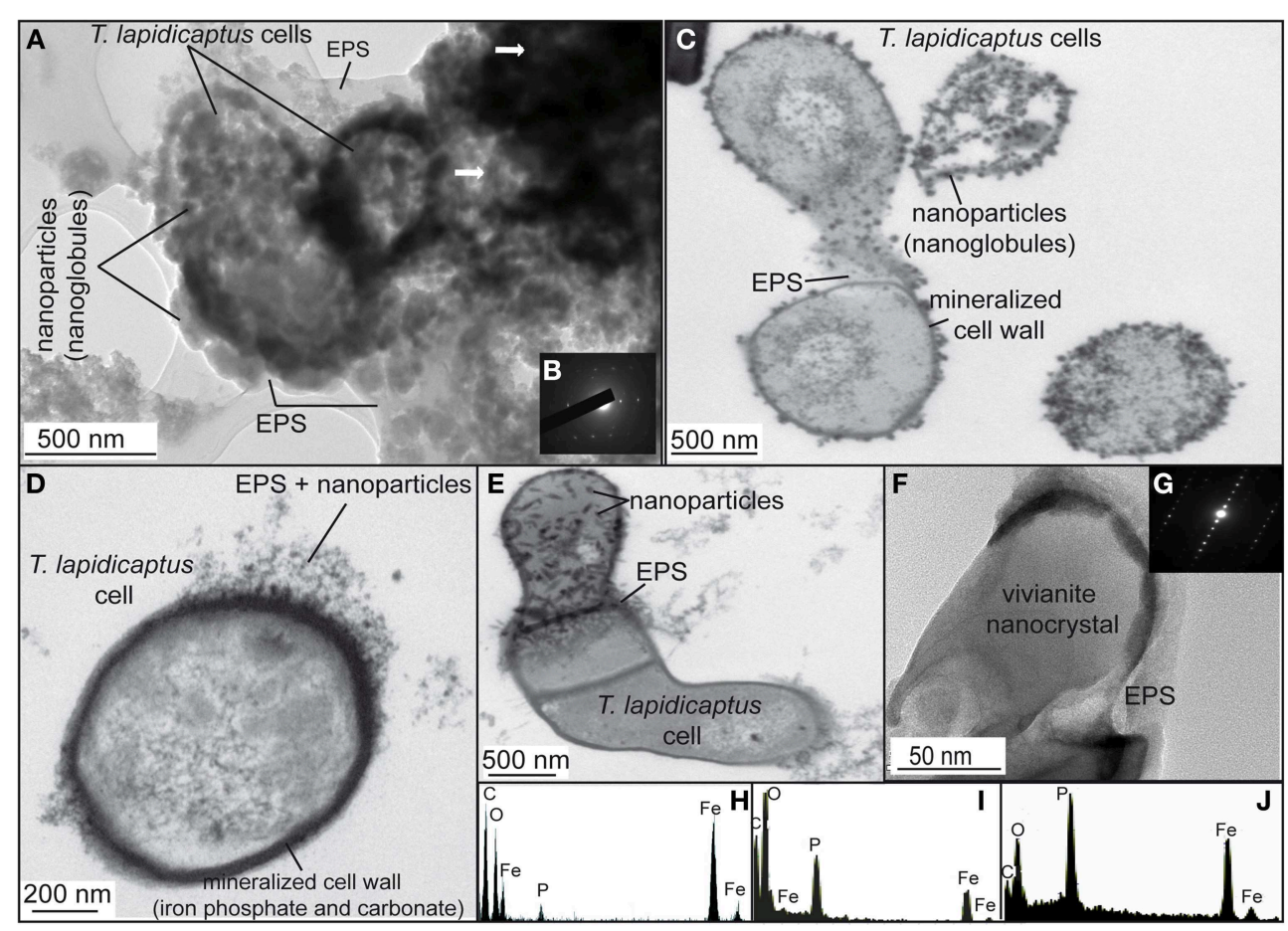

FIGURE 2 | TEM images of the bioprecipitates formed in $\boldsymbol{T}$. Lapidicaptus anaerobic cultures. (A) The bioprecipitates are nanoparticles attached to T. lapidicaptus cell and its secreted EPS, respectively. (B) Electron diffraction pattern of the darker areas, more mineralized areas. (C) T. lapidicaptus cells with mineralized cell wall and covered by nanoparticles embeded in EPS. (D) Detail of T. lapidicaptus cell with mineralized cell wall. Note nanoparticles embedded in EPS. (E) Detail of three cells together with mineralized cell wall and EPS. The upper cell covered by nanoparticles embedded in EPS. (F) Elongated nanoparticle, vivianite nanocrystal, embedded in EPS. (G) Electron diffraction pattern of the nanocrystal (F). (H,I) EDX spectra of both dark and lighter mineralized areas (1A) composed of Fe-carbonate and phosphate, respectively. (J) EDX spectrum of nanoparticle (1E) composed of Fe-phosphate (vivianite).

phosphates are hydrolysed by phosphatases, which liberate orthophosphate during microbial decomposition of organic material. Locally elevated orthophosphate, excreted during microbial decomposition of organic material (yeast extract), around bacterial cells becomes available together with the inorganic phosphate and soluble iron $\left(\mathrm{Fe}^{2+}\right)$ initially present in the culture medium for the precipitation of vivianite. Hence, the precipitation of Fe-phosphate (vivianite) removes $\mathrm{PO}_{4}{ }^{3-}$ ions from the solution, leading to the precipitation of Fe-carbonate (siderite). Thus, we propose that vivianite and siderite are authigenic sedimentary minerals that require similar physico-chemical conditions to precipitate and the presence of microorganisms.

\section{Significance and Implications of Vivianite and Siderite in Natural Systems}

In our aqueous solutions, conditions for the precipitation of $\mathrm{Fe}$ carbonates are created after phosphate precipitation. Thus, we propose that in environments with sufficient phosphate and iron, vivianite will precipitate first than siderite, while in environments with $\mathrm{PO}_{4}{ }^{3-}$ deficiency siderite will precipitate first. The same phenomenon might be occurring in Rio Tinto subsurface, from where T. lapidicaptus has been isolated (Puente-Sánchez et al., 2014a), characterized by the presence of iron sulfide (pyrite) and carbonate (siderite) minerals (Fernández-Remolar et al., 2012).
However, Fe-phosphates have not yet been detected there, even though vivianite is considered as an alteration of pre-existing Fe-carbonates or sulfides (Garvin, 1998). This could be due to the presence of abundant dissolve sulfide, which inhibits the formation of vivianite (Postma, 1981; Manning et al., 1999). The reduction of aqueous or embedded sulfate coupled to organic matter oxidation would lead to the formation of $\mathrm{H}_{2} \mathrm{~S}$ and carbonate. $\mathrm{H}_{2} \mathrm{~S}$ subsequently reacts with iron, and contributes to the formation of $\mathrm{FeS}_{2}$ whereas $\mathrm{CO}_{3}{ }^{2-}$ would react with iron to precipitate carbonate $\left(\mathrm{FeCO}_{3}\right)$. Then, the absence of phosphate minerals in Rio Tinto may be linked to the presence of sulfate (Puente-Sánchez et al., 2014b) and its microbiological transformation to $\mathrm{H}_{2} \mathrm{~S}$ with the consequently formation of pyrite. It is probably for this reason that we rarely find vivianite occurring in nature. In fact, it only persists in reducing organicrich environments (lakes, deep-sea sediments, swamps, sewage) with low concentrations of sulfate, which results in a high and continuous precipitation of vivianite. Our experimental findings provide information that could be used to interpret the role of microorganisms in digenetic mineral processes resulting in phosphate and carbonate formation in natural systems.

On the other hand, supersaturated solutions (e.g., interstitial pore water) cannot serve as reliable predictors for the in situ formation of phosphates (Rothe et al., 2014). A gel-like pore structure (Rothe et al., 2014) of a sediment matrix rich in organic 


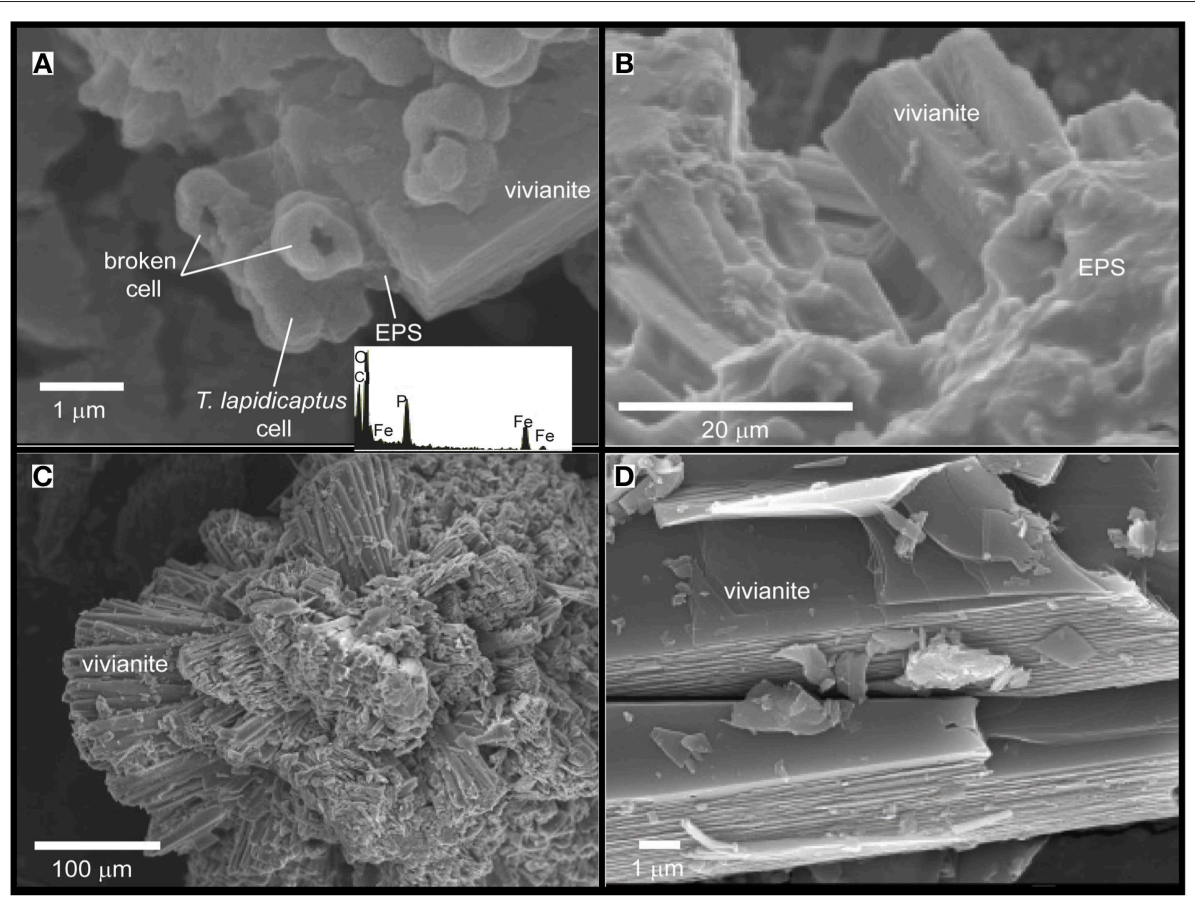

FIGURE 3 | SEM images of the Fe-phosphate precipitates from T. Lapidicaptus anaerobic cultures. EDX spectrum of mineralized cell displaying C, O, Fe, and P. (A) Vivianite crystal attached to mineralized T. lapidicaptus cells and EPS. (B) Elongated vivianite crystal embedded in EPS. (C) Rosette formation of crystal clusters of vivianite. (D) Vivianite crystals with prismatic or tabular habit.

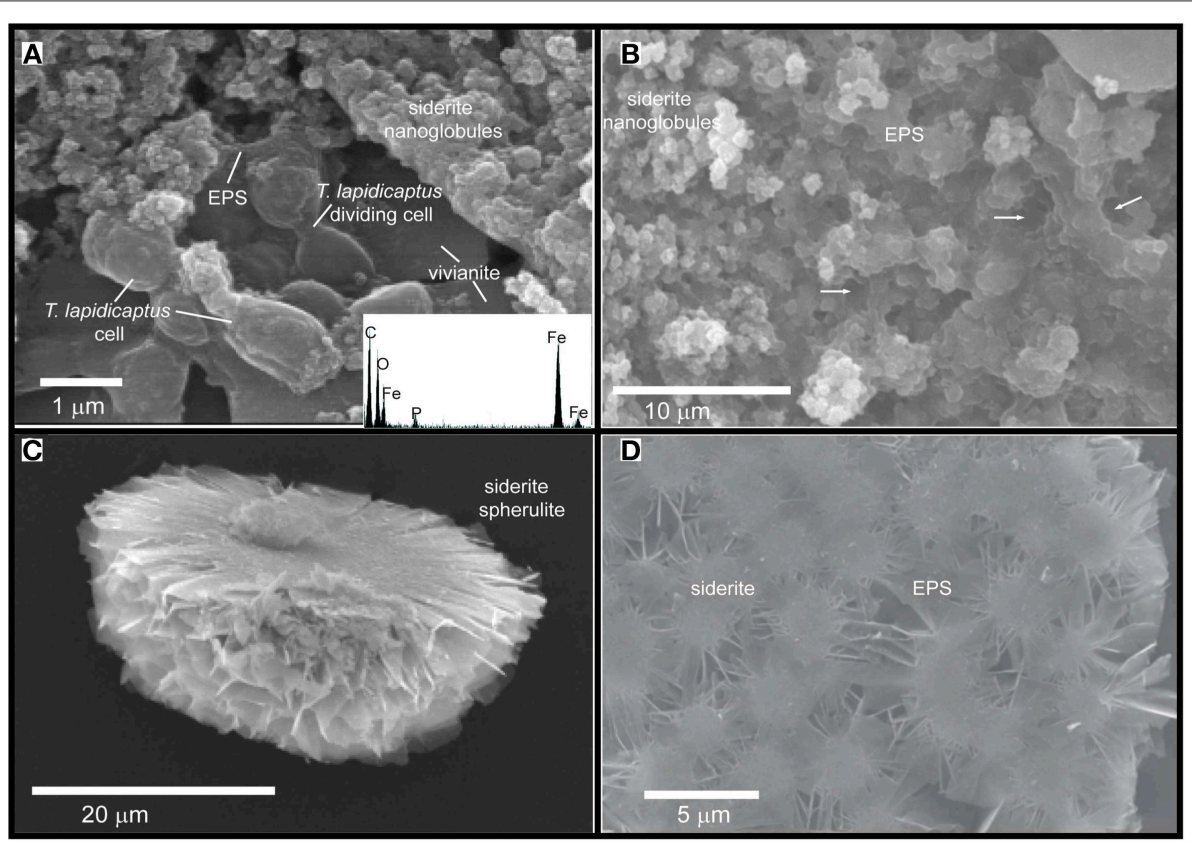

FIGURE 4 | SEM images of the Fe-carbonate precipitates from T. Lapidicaptus anaerobic cultures. (A) Siderite nanoglobules embedded in EPS and attached to mineralized dividing T. Lapidicaptus cells. Note the vivianite crystal attached to these cells. EDX spectrum of mineralized cell displaying C, O, Fe, and small peak of P. (B) Fe-carbonate nanoglobules (siderite) embedded in EPS and delimiting the bacterial cell contours (white arrows). These nanostructures display granulated texture. White arrows correspond to moulds of degraded bacteria (broken cells). (C) Broken microspherulite of siderite. (D) Detail of a siderite spherulite which formed by aggregation of nanoparticles. 
TABLE 1 | Saturation index values (SI) in FE anaerobic medium.

\begin{tabular}{lc}
\hline Mineral phase & SI \\
\hline Aragonite, $\mathrm{CaCO}_{3}$ & -1.16 \\
Artinite, $\mathrm{Mg}_{2}\left(\mathrm{CO}_{3}\right)(\mathrm{OH})_{2} \times 3 \mathrm{H}_{2} \mathrm{O}$ & -8.45 \\
Brucite, $\mathrm{Mg}(\mathrm{OH})_{2}$ & -6.76 \\
Calcite, $\mathrm{CaCO}$ & -1.02 \\
Dolomite, $\mathrm{CaMg}\left(\mathrm{CO}_{3}\right)_{2}$ & -1.34 \\
Halite, $\mathrm{NaCl}$ & -4.61 \\
Huntite, $\mathrm{CaMg}\left(\mathrm{CO}_{3}\right)_{4}$ & -5.98 \\
Hydroxiapatite $\mathrm{Ca}_{5}\left(\mathrm{PO}_{4}\right)_{3} \mathrm{OH}$ & 2.48 \\
Magnesite, $\mathrm{MgCO}_{3}$ & -0.81 \\
Natron, $\mathrm{Na}_{2} \mathrm{CO}_{3} \times 1 \mathrm{OH}_{2} \mathrm{O}$ & -7.46 \\
Nesquehonite, $\mathrm{MgCO}_{3} \times 3 \mathrm{H}_{2} \mathrm{O}$ & -3.22 \\
Siderite, $\mathrm{FeCO}_{3}$ & 2.40 \\
Vivianite, $\mathrm{Fe}_{3}\left(\mathrm{PO}_{4}\right)_{2} \times 8 \mathrm{H}_{2} \mathrm{O}$ & 9.08 \\
\hline
\end{tabular}

Results are from geochemical software PHREEQC. SI values are for initial conditions.

matter, in combination with release of soluble phosphorous and iron due to microbial activity, is necessary for vivianite formation in natural systems. In our culture experiments the gel-like pore structure would be the bacterial EPS and cell surfaces which throughout bacterial activity (1) create local microenvironments supersaturated with respect to phosphates and carbonates; and (2) act as templates for mineral nucleation overcoming the kinetic barriers of mineral precipitation. Indeed, similar nanocrystals of phosphate and carbonate to the ones shown in the present study (Figures $2 \mathrm{~A}, \mathbf{E}, \mathbf{4 A}, \mathbf{B}$ ) have been also reported as closely linked to the presence of bacterial cells, EPS and similar mucilaginous structures in modern and ancient environments (Sánchez-Román et al., 2008; Crosby and Bailey, 2012; Cosmidis et al., 2013, 2014; Sánchez-Navas et al., 2013). The preservation of these nanostructures in the geological record

\section{References}

Aloisi, G., Gloter, A., Krúger, M., Wallmann, K., Guyot, F., and Zuddas, P. (2006). Nucleation of calcium carbonate on bacterial nanoglobules. Geology 34, 1017-1020. doi: 10.1130/G22986A.1

Amils, R., Fernández-Remolar, D., Parro, V., Rodríguez-Manfredi, J. A., Timmis, K., Oggerín, M., et al. (2013). Iberian Pyrite Belt Subsurface Life (IPBSL), a drilling project of biohydrometallurgical interest. Adv. Mat. Res. 825, 15-18. doi: 10.4028/www.scientific.net/AMR.825.15

Berner, R. A. (1980). Early Diagenesis. Princeton, NJ: Princeton University Press.

Beveridge, T. J., and Fyfe, W. S. (1985). Metal fixation by bacterial cell walls. Can. J. Earth Sci. 22, 1892-1898. doi: 10.1139/e85-204

Bontognali, T. R. R., Vasconcelos, C., Warthmann, R., Dupraz, C., Bernasconi, S. M., and McKenzie, J. A. (2008). Microbes produce nanobacteria-like structures, avoiding cell entombment. Geology 36, 663-666. doi: 10.1130/G2 4755A.1

Bouropoulos, N. C., and Koutsoukos, P. G. (2000). Spontaneous precipitation of struvite from aqueous solutions. J. Crys. Growth 213, 381-388. doi: 10.1016/S0022-0248(00)00351-1

Bosak, T., and Newman, D. K. (2003). Microbial nucleation of calcium carbonate in the Precambrian. Geology 31, 577-580. doi: 10.1130/00917613(2003)031\%3C0577:MNOCCI\%3E2.0.CO;2

Cai, M., Wang, L., Cai, H., Li, Y., Wang, Y. N., Tang, Y. Q., et al. (2011). Salinarimonas ramus sp. nov. and Tessaracoccus oleiagri sp. nov., isolated from may help us to trace microbial processes through geologic time. Therefore, this experimental study (1) may help to understand the formation of ancient iron phosphate (Fife and Mark, 1982; Cook and Shergold, 1986; Simonen, 1986) and carbonate (Veizer et al., 1989; Ohmoto et al., 2004) deposits, and (2) provides potential biosignatures that may be useful to test terrestrial and extraterrestrial habitats for life evidences.

Finally, our experiments demonstrate that T. lapidicaptus can cause considerable iron accumulation through biomineralization of phosphate and carbonate, therefore, T. lapidicaptus could be considered a good phosphate removing bacterium from anaerobic systems. Furthermore, vivianite and siderite produced by $T$. lapidicaptus could be a good alternative fertilizer of phosphorous and iron. The presence of this bacterium and/or related bacteria in natural environments could explain the formation of vivianite and siderite. The co-precipitation of $\mathrm{Fe}$ phosphate and carbonate in our cultures links the $\mathrm{P}, \mathrm{C}$, and Fe cycles during biomineralization.

\section{Author Contributions}

MS and FP designed the culture experiments and performed all the laboratory tasks, carried out the culture experiments. MS wrote the first draft of the manuscript. FP, VP, and RA assisted in preparing the manuscript, all authors read and approved the final version.

\section{Acknowledgments}

This work was supported by the European Research Council Advanced Grant ERC-250350/IPBSL, and the Spanish Ministry of Economy and Competitiveness AYA2011-24803 projects. We also acknowledge Nuria Rodriguez for her assistance with some of the SEM analyses. a crude oil-contaminated saline soil. Int. J. Syst. Evol. Microbiol. 61, 1767-1775. doi: 10.1099/ijs.0.025932-0

Cook, P. J., and Shergold, J. H. (1986). Phosphate Deposits of the World: Vol. 1: Proterozoic and Cambrian Phosphorites. Cambridge: Cambridge University Press.

Cosmidis, J., Benzerara, K., Gheerbrant, E., Estève, I., Bouya, B., and Amaghzaz, M. (2013). Nanometer-scale characterization of exceptionally preserved bacterial fossils in paleocene phosphorites from ouled abdoun (Morocco). Geobiology 11, 139-153. doi: 10.1111/gbi.12022

Cosmidis, J., Benzerara, K., Morin, G., Busigny, V., Lebeau, O., Jézéquel, D., et al. (2014). Biomineralization of iron-phosphates in the water column of Lake Pavin (Massif Central, France). Geochim. Cosmochim. Acta 126, 78-96. doi: 10.1016/j.gca.2013.10.037

Craig, J. R., and Vaughan, D. J. (1994). Ore Microscopy and Ore Petrography, 2nd Edn. New York, NY: Wiley.

Crosby, C. H., and Bailey, J. V. (2012). The role of microbes in the formation of modern and ancient phosphatic mineral deposits. Front. Microbiol. 3:241. doi: 10.3389/fmicb.2012.00241

De Yoreo, J. J., Waychunas, G. A., Jun, Y. S., and Fernandez-Martinez, A. (2013). In situ investigations of carbonate nucleation on mineral and organic surfaces. Rev. Mineral. Geochem. 77, 229-257. doi: 10.2138/rmg.2013.77.7

Dijkstra, N., Kraal, P., Kuypers, M. M. M., Schnetger, B., and Slomp, C. P. (2014). Are iron-phosphate minerals a sink for phosphorous in anoxic black sea sediments? PLoS ONE 9:e101139. doi: 10.1371/journal.pone.0101139 
Dupraz, C., Reid, R. P., Braissant, O., Decho, A. W., Norman, R. S., and Visscher, P. T. (2009). Processes of carbonate precipitation in modern microbial mats. Earth Sci. Rev. 96, 141-162. doi: 10.1016/j.earscirev.2008.10.005

Dupraz, C., Visscher, P. T., Baumgartner, L. K., and Reid, R. P. (2004). Microbemineral interactions: early carbonate precipitation in a hypersaline lake (Eleuthera Island, Bahamas). Sedimentology 51, 745-765. doi: 10.1111/j.13653091.2004.00649.x

Dyar, M. D., Jawin, E. R., Breves, E., Marchand, G., Nelms, M., Lane, M. D., et al. (2014). Mössbauer parameters of iron in phosphate minerals: implications for interpretation of martian data. Am. Mineral. 99, 914-942, doi: 10.2138/am.2014.4701

Ehrlich, H. L. (2002). Geomicrobiology, 4th Edn. New York, NY: Marcel Dekker.

Ellwood, B. B., Chrzanowski, T. H., Hrouda, F., Long, G. J., and Buhl, M. L. (1998). Siderite formation in anoxic deep-sea sediments: a synergetic bacteria controlled process with important implications in paleomagnetism. Geology 16, 980-982.

Ercole, C., Cacchio, P., Botta, A. L., Centi, V., and Lepidi, A. (2007). Bacterially induced mineralization of calcium carbonate: the role of exopolysaccharides and capsular polysaccharides. Microsc. Microanal. 13, 42-50. doi: 10.1017/S1431927607070122

Eynard, A., del Campillo, M. C., Barron, V., and Torrent, J. (1992). Use of vivianite $\left(\mathrm{Fe}_{3}\left(\mathrm{PO}_{4}\right)_{2} \times 8 \mathrm{H}_{2} \mathrm{O}\right)$ to prevent iron chlorosis in calcareous soils. Fert. Res. 31, 61-67. doi: 10.1007/BF01064228

Fairen, A., Fernández-Remolar, D., Dohm, J. M., Baker, V. R., and Amils, R. (2004). Inhibition of carbonates synthesis in acidic oceans on early Mars. Nature 431, 423-426. doi: 10.1038/nature02911

Fernández-Remolar, D. C., Preston, L. J., Sánchez-Román, M., Izawa, M. R. M., and Huang, L. (2012). Carbonate precipitation under bulk acidic conditions as a potential biosignature for searching life on Mars. Earth. Planet. Sci. Lett. 351-352, 13-26. doi: 10.1016/j.epsl.2012.07.015

Ferrero, J. J., Alvarez, A. M., Ramírez-Franco, J., Godino, M. C., and Bartolomé-Martín, D. (2013). $\beta$-Adrenergic receptors activate exchange protein directly activated by cAMP (Epac), translocate Munc13-1, and enhance the Rab3A-RIM1a interaction to potentiate glutamate release at cerebrocortical nerve terminals. J. Biol. Chem. 288, 31370-31385. doi: 10.1074/jbc.M113. 463877

Fife, D. L., and Mark, E. B. (1982). Significance of Neogene phosphorites in Capistrano embayment, Southern California. AAPG Bull. 66, 1688.

Finster, K. W., Cockell, C. S., Voytek, M. A., Gronstal, A. L., and Kjeldsen, K. U. (2009). Description of Tessaracoccus profundi sp.nov., a deepsubsurface actinobacterium isolated from a Chesapeake impact crater drill core (940 m depth). Ant. van Leeuwen. 96, 515-526. doi: 10.1007/s10482-0099367-y

Fredrickson, J. K., and Gorby, Y. A. (1996). Environmental processes mediated by iron-reducing bacteria. Curr. Opin. Biotechnol. 7, 287-294. doi: 10.1016/S09581669(96)80032-2

Fredrickson, J. K., Zachara, J. M., Kennedy, D. W., Dong, H., Onslott, T. C., Hinman, N. W., et al. (1998). Biogenic iron mineralization accom- panying the dissimilatory reduction of hydrous ferric oxide by a groundwater bacterium. Geochim. Cosmochim. Acta 62, 3239-3257. doi: 10.1016/S0016-7037(98) 00243-9

Garvin, P. (1998). Iowa's Minerals: Their Occurrence, Origins, Industries, and Lore. Iowa City, IA: University of Iowa Press.

Glasauer, S., Weidler, P. G., Langley, S., and Beveridge, T. J. (2003). Controls on Fe reduction and mineral formation by a subsurface bacterium. Geochim. Cosmochim. Acta 67, 1277-1288. doi: 10.1016/S0016-7037(02)01199-7

Habraken, W. J., Tao, J., Brylka, L. J., Friedrich, H., Bertinetti, L., Schenk, A. S., et al. (2013). Ion-association complexes unite classical and non-classical theories for the biomimetic nucleation of calcium phosphate. Nat. Commun. 4, 1507. doi: 10.1038/ncomms 2490

Jack, T. R., Ferris, F. G., Stehmeier, L. G., Kantzas, A., and Marentette, D. F. (1993). "Bug rock: bacteriogenic mineral precipitation systems for oil patch use," in Developments in Petroleum Science in Microbial Enhancement of Oil Recovery-Recent Advances, eds E. T. Premuzic and A. Woodhead (Amsterdam, NY: Elsevier), 27-35.

Jakobsen, B. H. (1988). Accumulation of pyrite and Fe-rich carbonate and phosphate minerals in a lowland moor area. J. Soil Sci. 39, 447-455. doi: 10.1111/j.1365-2389.1988.tb01230.x
Kämpfer, P., Lodders, N., Warfolomeow, I., and Busse, H. J. (2009). Tessaracoccus lubricantis sp. nov., isolated from a metalworking fluid. Int. J. Syst. Evol. Microbiol. 59, 1545-1549. doi: 10.1099/ijs.0.006841-0

Kholodov, V. N., and Butuzova, G. Y. (2008). Siderite formation and evolutions of sedimentary iron ore deposition in the Earth's history. Geol. Ore Deposits 50, 299-319. doi: 10.1134/S107570150804003X

Kofina, A. N., and Kotsoukos, P. G. (2005). Spontaneous precipitation of struvite from synthetic wastewater solutions. Cryst. Growth Des. 5, 489-496. doi: $10.1021 / \operatorname{cg} 049803 \mathrm{e}$

Konhauser, K. O. (1998). Diversity of bacteria iron mineralization. Earth Sci. Rev. 43, 91-121. doi: 10.1016/S0012-8252(97)00036-6

Krause, S., Liebetrau, V., Goeb, S., Sánchez-Román, M., McKenzie, J. A., and Treude, T. (2012). Microbial nucleation of Mg-rich dolomite in exopolymeric substances under anoxic modern seawater salinity: new insight into an old enigma. Geology 40, 587-590. doi: 10.1130/G32923.1

Last, W. M., and De Deckker, P. (1990). Modern and Holocene carbonate sedimentology of two saline volcanic maar lakes, southern Australia. Sedimentology 37, 967-981. doi: 10.1111/j.1365-3091.1990.tb01839.x

Lee, D. W., and Lee, S. D. (2008). Tessaracoccus flavescens sp. nov., isolated from marine sediment. Int. J. Syst. Evol. Microbiol. 58, 785-789. doi: 10.1099/ijs.0.64868-0

Lee, S. Y., Yoshikawa, H., and Matsui, T. (2010). Biomineralization of vivianite on the carbon steel surface attacked by the iron reducing bacteria. MRS Proc. 1265:AA06-01. doi: 10.1557/proc-1265-aa06-01

Lemos, V. P., Lima da Costa, M., and Lemos, R. L. (2007). Vivianite and siderite in lateritic iron crust: an example of bioreduction. Quim. Nova 30, 36-40. doi: 10.1590/S0100-40422007000100008

Lovley, D. R., Phillips, E. J. P., and Lonergan, D. J. (1991). Enzymatic versus nonenzymic mechanisms for iron (III) reduction in aquatic sediments. Environ. Sci. Technol. 25, 1062-1067 doi: 10.1021/es00018a007

Manning, P. G., Murphy, T. P., and Prepas, E. E. (1991). Intensive formation of vivianite in the bottom sediments of mesotrophic Narrow Lake, Alberta. Can. Mineral. 29, 77-78.

Manning, P. G., Prepas, E. E., and Serediak, M. S. (1999). Pyrite and vivianite intervals in the bottom sediments of eutrophic Baptiste lake, Alberta, Canada. Can. Mineral. 37, 593-601.

McGowan, G., and Prangnell, J. (2006). The significance of vivianite in archeological settings. Geoarcheology 21, 93-111. doi: 10.1002/gea.20090

Mikhailov, V. (1940). Vivianite as fertilizer for industrial potatoes. Spirto-Vodoch. Prom. 17, 14-15.

Moore, C. H. (1989). "The nature of carbonate depositional systems-comparison of carbonates and siliciclastics," in Developments in Sedimentology 46, ed C. H. Moore (Amsterdam: Elsevier), 1-19.

Morse, J. W. (1983). "The kinetics of calcium carbonate dissolution and precipitation," in Reviews in Mineralogy: Carbonates-Mineralogy and Chemistry, ed R. J. Reeder (Chelse, MA: Mineralogical Society of America, Bookcrafters, Inc.), 227-264.

Morse, J. W., Arvidson, R. S., and Lüttge, A. (2007). Calcium carbonate formation and dissolution. Chem. Rev. 107, 342-381. doi: 10.1021/cr050358j

Mortimer, R. J. G., and Coleman, M. (1997). Microbial influence on the oxygen isotopic composition of diagenetic siderite. Geochim. Cosmochim. Acta 61, 1705-1711. doi: 10.1016/S0016-7037(97)00027-6

Nelipa, K. V. (1961). Vivianite - a source of phosphorous for plant nutrition. Uchenye Zapiski Michurink Gosndarst Pedagog Inst. 8, 65-80.

Nriagu, J. O., and Dell, C. I. (1974). Diagenetic formation of iron phosphates in recent lake sediments. Am. Mineral. 59, 934-946.

Nutt, M. L., and Swihart, G. H. (2012). Phosphate mineralization at Nonconnah Creek, Menphis, Tennessee. J. Tennessee Acad. Sci. 87, 126.

Oggerin, M., Tornos, F., Rodríguez, N., del Moral, C., Sánchez-Román, M., and Amils, R. (2013). Specific jarosite biomineralization by Purpureocillium lilacinum, an acidophilic fungi isolated from Río Tinto. Environ. Microbiol. 15, 2228-2237. doi: 10.1111/1462-2920.12094

Ohmoto, H., Watanabe, Y., and Kumazawa, K. (2004). Evidence from massive siderite beds for a CO2-rich atmosphere before $\sim 1.8$ billion years ago. Nature 429, 395-399. doi: 10.1038/nature02573

Orange, F., Westall, F., Disnar, J. R., Prieur, D., Bienvenu, N., Le Romancer, M., et al. (2009). Experimental silicification of the extremophilic Archaea Pyrococcus abyssi and Methanocaldococcus jannaschii: applications in the 
search for evidence of life in early Earth and extraterrestrial rocks. Geobiology 7, 403-418. doi: 10.1111/j.1472-4669.2009.00212.x

Parkhust, D. L., and Appelo, C. A. J. (1999). User's Guide to Phreeqc (version 2) - a Computer Program for Speciation, Batchreaction, One-Dimensional Transport, and Inverse Geochemical Calculations. Water-Resources Investigations Report, 99-4259, US Geological Survey, Denver, CO.

Postma, D. (1981). Formation of siderite and vivianite and the porewater composition of a recent bog sediment in Denmark. Chem. Geol. 31, 225-244. doi: 10.1016/0009-2541(80)90088-1

Puente-Sánchez, F., Moreno-Paz, M., Rivas, L. A., Cruz-Gil, P., GarcíaVilladangos, M., Gómez, M. J., et al. (2014b). Deep subsurface sulfate reduction and methanogenesis in the Iberian Pyrite Belt revealed through geochemistry and molecular biomarkers. Geobiology 12, 34-47. doi: 10.1111/gbi. 12065

Puente-Sánchez, F., Sánchez-Román, M., Amils, R., and Parro, V. (2014a). Tessaracoccus lapidicaptus sp. nov., a novel actinobacterium isolated from the deep subsurface of the Iberian Pyritic Belt (Huelva, Spain). Int. J. Syst. Evol. Microbiol. 64, 3546-3552. doi: 10.1099/ijs.0.060038-0

Raiswell, R., and Canfield, D. (2012). The iron biogeochemical cycle past and present. Geochem. Perspect. 1, 1-220. doi: 10.7185/geochempersp.1.1

Rakshit, S., Matocha, J. C., and Coyne, M. S. (2008). Nitrite reduction by siderite. Soil Sci. Soc. Am. J. 72, 1070-1077. doi: 10.2136/sssaj2007.0296

Ridgwell, A., and Zeebe, R. E. (2005). The role of the global carbonate cycle in the regulation and evolution of the Earth system. Earth Planet. Sci. Lett. 234, 299-315. doi: 10.1016/j.epsl.2005.03.006

Riding, R. (2006). Microbial carbonate abundance compared with fluctuations in metazoan diversity over geological time. Sediment. Geol. 185, 229-238. doi: 10.1016/j.sedgeo.2005.12.015

Rothe, M., Frederichs, T., Eder, M., Kleeberg, A., and Hupfer, M. (2014). Evidence for vivianite formation and its contribution to long-term phosphorus retention in a recent lake sediment: a novel analytical approach. Biogeosciences 11, 5169-5180. doi: 10.5194/bg-11-5169-2014

Sánchez-Alcalá, I., del Campillo, M. C., Barrón, V., and Torrent, J. (2012). Post evaluation of synthetic nanosiderite for the prevention of iron chlorosis. J. Sci. Food Agric. 92, 1964-1973. doi: 10.1002/jsfa.5569

Sánchez-Navas, A., Martín-Algarra, A., Rivadeneyra, M. A., Melchor, S., and Martín Ramos, J. D. (2009). Crystal-growth behavior in Ca-Mg carbonate bacterial spherulites. Cryst. Growth Des. 9, 2690-2699. doi: 10.1021/cg80 $1320 \mathrm{p}$

Sánchez-Navas, A., Martín-Algarra, A., Sánchez-Román, M., Jiménez-López, C., Nieto, F., and Ruiz-Bustos, A. (2013). "Crystal growth of inorganic and biomediated carbonates and phosphates," in Advanced Topics on Crystal Growth, ed S. Olavo Ferreira (Rijeka: InTech), 67-88.

Sánchez-Román, M., Fernández-Remolar, D., Amils, R., Sánchez-Navas, A., Schmid, T., San Martin-Uriz, P., et al. (2014). Microbial mediated formation of Fe-carbonate minerals under extreme acidic conditions. Sci. Rep. 4:4767. doi: 10.1038/srep04767

Sánchez-Román, M., Romanek, C. S., Fernández-Remolar, D. C., Sánchez-Navas, A., McKenzie, J. A., Amils, R., et al. (2011). Aerobic biomineralizacion of Mg-rich carbonates: implications for natural environments. Chem. Geol. 281, 143-150. doi: 10.1016/j.chemgeo.2010.11.020

Sánchez-Román, M., Vasconcelos, C., Schmid, T., Dittrich, M., McKenzie, J. A., Zenobi, R., et al. (2008). Aerobic microbial dolomite at the nanometer scale: implicatios for the geologic record. Geology 36, 879-882. doi: 10.1130/G25013A.1

Sapota, T., Aldahan, A., and Al-Asam, I. S. (2006). Sedimentary facies and climate control on formation of vivianite and siderite microconcretions in sediments of Lake Baikal, Siberia. J. Paleolimmnol. 36, 245-257. doi: 10.1007/s10933-0069005-x

Schultze-Lam, S., Fortin, D., Davis, B. S., and Beveridge, T. J. (1996). Mineralization of bacterial surfaces. Chem. Geol. 132, 171-181 doi: 10.1016/S0009-2541(96)00053-8

Simonen, A. (1986). Vivianite from Paakkila, Tuusniemi, Finland. Bull. Geol. Soc. Finl. 58, 271-275.

Thali, M. J., Lux, B., Lösch, S., Rösing, F. W., Hürlimann, J., Feer, P., et al. (2011). "Brienzi" - The blue Vivianite man of Switzerland: time since death estimation of an adipocere body. Forensic Sci. Int. 211, 34-40. doi: 10.1016/j.forsciint.2011.04.009

Tomkinson, T., Lee, M. R., Mark, D. F., and Smith, C. L. (2013). Sequestration of Martian $\mathrm{CO}_{2}$ by mineral carbonation. Nature Comm. 4, 2662. doi: $10.1038 /$ ncomms 3662

Valley, J. W., Eiler, J. M., Graham, C. M., Gibson, E. K. Jr., Romanek, C. S., and Stolper, E. M. (1997). Low-temperature carbonate concretions in the martian meteorites ALH 84001: evidence from stable isotopes and mineralogy. Science 275, 1633-1638.

van Lith, Y., Warthmann, R., Vasconcelos, C., and McKenzie, J. A. (2003). Sulphate-reducing bacteria induce low-temperature dolomite and high $\mathrm{Mg}$ calcite formation. Geobiology 1, 71-79. doi: 10.1046/j.1472-4669.2003.00003.x

Veeramani, H., Alessi, D. S., Suvorova, E. I., Lezama-Pacheco, J. S., Stubbs, J. E., Sharp, J. O., et al. (2011). Products of abiotic U(VI) reduction by biogenic magnetite and vivianite. Geochim. Cosmochim. Acta 75, 2512-2528. doi: 10.1016/j.gca.2011.02.024

Veizer, J., Hoefs, J., Lowe, D. R., and Thurston, P. C. (1989). Geochemistry of precambrian carbonates: II. Archean greenstone belts and Archean sea water. Geochim. Cosmochim. Acta 53, 859-871. doi: 10.1016/0016-7037(89)90031-8

Vuillemin, A., Ariztegui, D., De Coninck, A. S., Lücke, A., Mayr, C., Schubert, C. J., et al. (2013). Origin and significance of diagenetic conditions in sediments of Laguna Potrok Aike, southern Argentina. J. Paleolimnol. 50, 275-291. doi: 10.1007/s10933-013-9723-9

Wiberg, E., Wiberg, N., and Holleman, A. F. (2001). Inorganic Chemistry. San Diego, CA: Academic Press.

Wilkinson, M., Haszeldine, R. S., Fallick, A. E., and Osborne, M. J. (2000). Siderite zonation within the Brent Group: microbial influence or aquifer flow? Clay Miner. 35, 111-121. doi: 10.1180/000985500546512

Conflict of Interest Statement: The authors declare that the research was conducted in the absence of any commercial or financial relationships that could be construed as a potential conflict of interest.

Copyright (c) 2015 Sánchez-Román, Puente-Sánchez, Parro and Amils. This is an open-access article distributed under the terms of the Creative Commons Attribution License (CC BY). The use, distribution or reproduction in other forums is permitted, provided the original author(s) or licensor are credited and that the original publication in this journal is cited, in accordance with accepted academic practice. No use, distribution or reproduction is permitted which does not comply with these terms. 